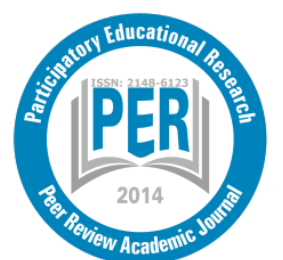

Participatory Educational Research (PER)

Vol. 7(2), pp. 135-150, August 2020

Available online at http://www.perjournal.com

ISSN: 2148-6123

http://dx.doi.org/10.17275/per.20.24.7.2

\title{
Assessing Psychosocial Outdoor Learning Environment of Pre-service Science Teachers through The Field Trip Experiences
}

\author{
Rukhaini Fitri Rahmawati ${ }^{1}$, Muhamad Imaduddin ${ }^{2 *}$, Arghob Khofya Haqiqi ${ }^{3}$, \\ Achmad Ali Fikri ${ }^{4}$, Ulya Fawaida ${ }^{5}$, Dody Rahayu Prasetyo ${ }^{6}$ \\ Faculty of Education (Tarbiyah), Institut Agama Islam Negeri Kudus, Indonesia \\ ${ }^{1}$ https://orcid.org/0000-0003-1176-7517, ${ }^{2}$ https://orcid.org/0000-0002-3619-9985, \\ ${ }^{3}$ https://orcid.org/0000-0003-2820-2213, ${ }^{4}$ https://orcid.org/0000-0002-2950-4865, ${ }^{5}$ https://orcid.org/0000- \\ 0001-6115-1409, ${ }^{6}$ https://orcid.org/0000-0003-1887-4219
}

\section{Chatree Faikhamta \\ Faculty of Education, Kasetsart University, Bangkok, Thailand https://orcid.org/0000-0001-7364-9140}

\begin{tabular}{l}
\hline Article history \\
\hline Received: \\
28.01 .2020 \\
Received in revised form: \\
25.04 .2020 \\
Accepted: \\
30.04 .2020 \\
Key words: \\
\hline Psychosocial; \\
Outdoor learning environment; \\
Field trip; \\
Pre-service science teachers
\end{tabular}

Field trip activities are often considered additional activities and are considered recreational activities rather than ones that teach science effectively to students. Field trip activities are one form of effective experience-based learning to train pre-service teachers in the outdoor environment. This study attempted to describe the design of outdoor science learning in the form of the field trip for pre-service science teachers (PSTs) and the condition of psychosocial learning environments in outdoor activities. This research is a case study carried out in a pre-service science teacher training program at Institut Agama Islam Negeri Kudus, Indonesia. The field trip was designed with field visits on six objects for three days in Bandung, West Java, Indonesia. The field trip activity was attended by 70 PSTs. Qualitative data is captured through the documentation of activities at each outdoor learning location. Quantitative data collection instruments included seven psychosocial scales, namely (1) Environmental Interaction; (2) Integration; (3) Students cohesiveness; (4) Teacher supportiveness; (5) Open-endedness; (6) Preparation and organization; (7) Material environment. The field trip design for PSTs recommends activities that lead to observation and exploration of visiting objects relating not only to the content of the science but also to the pedagogical aspects of the science. The psychosocial aspects of PSTs indicate that field trip activities show a positive meaning in all aspects, although there are significant differences in the conditions of expectations and reality experienced by PSTs. The integration aspect is not significantly different. The decline in perception is still at the medium level, and the condition of the perception is still at a positive level. Research and development studies that emphasize the process of integrating classroom learning with outdoor activities can be carried out further to be able to give meaning to science learning, which is not limited by classrooms or laboratories.

\footnotetext{
*Correspondence: imad@iainkudus.ac.id
} 


\section{Introduction}

Science should be learned not only in the classroom or laboratory but also in the outdoor environment (Orion et al., 1997). However, many educators, researchers, or curriculum developers seem to have ignored the process of outdoor science learning (e.g., Orion \& Hofstein, 1994). Outdoor learning activities are often avoided by the relevant parties because they are not used to organizing field trip activities and may be far from understanding the techniques or underlying philosophies of visiting activities to teach science (Fido \& Gaylord, 1982; McKenzie et al., 1986). In fact, teachers who refrain from outdoor learning reflect the conditions of a limited understanding of the effectiveness of field trips. On the other hand, various studies also report varying forms of outdoor scientific learning that have an impact on increasing interest, desire, motivation, and other aspects of the learning process, also on learning science (Dillon et al., 2016; Hofstein \& Rosenfeld, 1996; Rickinson et al., 2004). Significant improvement witnessed in various aspects of cognitive, affective, social, and behavioral domains of the participants through outdoor learning. Activities in the visiting process can help students learn things from a variety of perspectives, and practice skills in accessing the content in new ways. This condition positively influences the achievements of children and adolescents (Marcus, 2008). Besides, students learn the process of transferring knowledge in a unique context, as well as gaining new knowledge through specific visits (Nadelson et al., 2012). The learning context helps learners remember the material being studied, along with that it enables to facilitate enthusiasm and a high level of participation.

Field trips are generally considered to have the potential to simplify complex ideas and to concretize abstract concepts through direct experience for students (Bell et al., 2009; Falk \& Balling, 1982; Orion \& Hofstein, 1994). Outdoor learning is also a form of contextualization of learning that can foster the improvement of the quality of learning design, encourage dialogue and interaction of students, as well as enhancing the comprehension of the meaning of lifelong learning (Ash \& Wells, 2006; Bamberger \& Tal, 2008; Martin, 2006). The experience gained by students through field trips allows students to feel a sense of involvement with natural or social phenomena that are real and is highly relevant to abstract material obtained in classroom learning (Knapp \& Barrie, 2001). Field trips provide opportunities for students to be more aware of the importance of maintaining and doing activities in favor of the interests of the environment (Ballantyne et al., 2007). Nevertheless, the number of studies that identify and assess outdoor education practices is still relatively low (Orion et al., 1997). The relationship between formal learning environments, that is schools and informal environments viz. field trips is apparently still not very clear (Bell et al., 2009). This very lack of clarity constitutes the biggest obstacle in the process of integrating indoor teaching with outdoor activities (Morag \& Tal, 2012). Field trip activities are often considered additional activities i.e. as cocurricular or even extra-curricular ones, and are more inclined to being evaluated as recreational activities rather than ones that teach science effectively to students.

Experience-based learning has been widely implemented in science teacher training programs. Pre-service teachers are trained with a variety of hands-on experience through their interactions with teachers, students, laboratory assistants, and school administration staff. Thus, they can improve the quality of science learning, at the same time master teacher competencies in the future (Matsko \& Hammerness, 2014). Field trip activities are one form of effective experience-based learning to train pre-service teachers apart from activities related to community service-based lectures (Zeichner, 2010). The design and implementation of field trips are two crucial points that need attention to be able to provide meaningful 
experiences for the participants and should be integrated with in class experiences (Djonkomoore \& Joseph, 2016). Field trips help pre-service teachers gain meaningful skills beyond acquisition through traditional lectures and seminar activities (Caires et al., 2012; Olgun, 2009).

It is important to know whether the field trip program organized for pre-service teachers is in line with expectations or not. The significance of the activity of field trips becomes an experience that can be used as a role model memory for teaching practices by PSTs. The exact condition of the field trip is observed to have been analyzed in the relevant literature through the perception of the conditions of the psychosocial learning environment of PSTs which included environmental interactions, integration of activities in the classroom and outside the classroom, student cohesiveness, teacher support, open-endedness, preparation and organization, as well as material environment (Ahmad et al., 2012; Fraser \& Treagust, 1986; Orion et al., 1997). Activities designed in a positive psychosocial environment stimulate intellectual activity, boost social contact, and promote student learning and development, and limit the occurrence and display of negative behavior among students. (Ahmad et al., 2012). This study discusses the design of field trip activities for PSTs as well as the psychosocial assessment of PSTs for content learning of science concepts from the perspective of expectations and the reality of field trip activities. Also, it is intended to cast light upon implementations of science education. This study bears importance as to reviewing the position of conducting field trips in the related educational process and with regard to the possible implementations of field trip activities for PSTs in the future serving as a basic model.

\section{Research question}

(1) What is the design of outdoor science learning in the form of field trips for PSTs?

(2) What is the psychosocial learning environment of PSTs in terms of the conditions of expectations from the activities and the reality that has been experienced after the field trip?

\section{Method}

\section{Research Design}

This research is a case study carried out in a pre-service teacher training program at Institut Agama Islam Negeri (IAIN) Kudus, Indonesia. Case studies are used to capture reality and provide a "thick description" of what is experienced in certain situations, namely outdoor learning activities (Cohen et al., 2007). Field trip events are inherently freer activities, yet data collection is done systematically and rigorously. This study highlights the field trip activities carried out on the object of the visit that is related to some aspects of science education, as well as concentrating upon the concept of applied science. The field trip was designed with field visits to six outdoor learning environment for three days in Bandung, West Java, which is about $500 \mathrm{~km}$ from IAIN Kudus, Central Java Province. These outdoor learning activities are integrated with several courses that were being taken by the PSTs then, which include the following courses: (1) Ecology, (2) Earth and Space Sciences, (3) Integrated Science, (4) Development of Media and ICT for Science, and (5) Teaching Profession. The courses are in the third year of their study. Survey activities are carried out on PSTs that participate in overall field trip activities. Details of each object observed and visited by PSTs are shown in Table 1. 
Table 1. List of Visiting Objects in Outdoor Activities

\begin{tabular}{|c|c|c|c|}
\hline No & Object of Visit & Description & Purposes of Activity \\
\hline 1 & $\begin{array}{l}\text { Cibodas Botanical } \\
\text { Garden }\end{array}$ & $\begin{array}{l}\text { The Technical Implementation Unit of the } \\
\text { Cibodas Botanical Garden Conservation Center } \\
\text { under the Bogor Botanical Gardens Conservation } \\
\text { Center in the Deputy of Biological Sciences, } \\
\text { Indonesian Institute of Sciences (LIPI). Details } \\
\text { can be accessed at https://krcibodas.lipi.go.id/ }\end{array}$ & $\begin{array}{l}\text { To provide an overview of } \\
\text { conservation management } \\
\text { and techniques for plants in } \\
\text { Indonesia }\end{array}$ \\
\hline 2 & $\begin{array}{lr}\text { Centre } & \text { for } \\
\text { Demonstration } & \text { of } \\
\text { Science and } & \text { and } \\
\text { Technology, Sundial }\end{array}$ & $\begin{array}{l}\text { A centre of exhibits of science and technology } \\
\text { which demonstration activities located in Kota } \\
\text { Baru Parahyangan, Padalarang, Bandung, West } \\
\text { Java. Details can be accessed at } \\
\text { https://thebiggestsundial.com/ }\end{array}$ & $\begin{array}{l}\text { To provide an overview of } \\
\text { the development of science } \\
\text { learning and teaching } \\
\text { media. }\end{array}$ \\
\hline 3 & $\begin{array}{lr}\text { Natural } & \text { Sciences } \\
\text { Education } & \text { Study } \\
\text { Program, } & \text { Indonesian } \\
\text { University } & \text { of } \\
\text { Education } & \end{array}$ & $\begin{array}{l}\text { Natural Sciences study program at the } \\
\text { undergraduate, master, and doctoral levels. Details } \\
\text { can be accessed at } \\
\text { http://ipse.upi.edu/ \& http://ipa.sps.upi.edu/ }\end{array}$ & $\begin{array}{l}\text { To provide an overview of } \\
\text { management education in } \\
\text { the undergraduate program } \\
\text { of natural science education } \\
\text { at other universities as well } \\
\text { as of opportunities to } \\
\text { continue their studies in the } \\
\text { field of science education }\end{array}$ \\
\hline 4 & $\begin{array}{lr}\text { SEAMEO } & \text { Regional } \\
\text { Centre for } & \text { Quality } \\
\text { Improvement } & \text { of } \\
\text { Teachers r and } \\
\text { Education Personnel } \\
\text { (QITEP) in Science }\end{array}$ & $\begin{array}{l}\text { The Institution of The Southeast Asian Ministers } \\
\text { of Education Organization (SEAMEO) Regional } \\
\text { Centre linked to Science Teachers and Education } \\
\text { personnel's Training. Details can be accessed at } \\
\text { https://www.qitepinscience.org/ }\end{array}$ & $\begin{array}{l}\text { To provide an overview of } \\
\text { organizations related to } \\
\text { science education that are } \\
\text { not school institutions. }\end{array}$ \\
\hline 5 & Pudak Scientific & $\begin{array}{l}\text { A national company that manufactures } \\
\text { educational teaching aids and laboratory } \\
\text { equipment. Details can be accessed at } \\
\text { http://www.pudak-scientific.com/ }\end{array}$ & $\begin{array}{l}\text { To provide an overview of } \\
\text { the production and } \\
\text { commercialization process } \\
\text { of educational teaching aids } \\
\text { and laboratory equipment to } \\
\text { support science learning } \\
\text { activities }\end{array}$ \\
\hline 6 & Boscha Observatory & $\begin{array}{l}\text { One of the oldest star observations in Indonesia. } \\
\text { Details can be accessed at } \\
\text { https://bosscha.itb.ac.id/ }\end{array}$ & $\begin{array}{l}\text { To provide an overview of } \\
\text { the activities of astronomers } \\
\text { in Indonesia. }\end{array}$ \\
\hline
\end{tabular}

\section{Participants}

The field trip activity was attended by 70 PSTs who were divided into two classes, that is to say, Class A and Class B in the fifth semester at the Natural Science Education Undergraduate Study Program. Class A and Class B were arranged in the first year of study. Participants stayed in the same class until the third year, during field trip activities. Class A consists of 6 males and 28 females, while class B consists of 8 males and 28 females. Before participating in this field trip program, four PSTs had visited Sundial, the Center for Demonstration of Science and Technology, one PST had visited the Cibodas Botanical Garden, and one other person had visited the Boscha Observatory.

\section{Data Collection and Analysis}

The data in this study is comprised of qualitative data that showed a series of activities on the field trip designed for PSTs, along with the quantitative data that showed PSTs' responses to field trip activities. Qualitative data is captured through the documentation of activities carried out by PSTs in each outdoor learning environment. Besides, quantitative data collection instruments were adapted according to the related context and rearranged concerning studies of Orion, Hofstein, Tamir, \& Giddings (1997) which included seven psychosocial scales which are (1) Environmental Interaction; (2) Integration; (3) Students cohesiveness; (4) Teacher supportiveness; (5) Open-endedness; (6) Preparation and 
organization; (7) Material environment. The scale is arranged in an instrument called The SOLEI (Science Outdoor Learning Environment Inventory). Each scale consists of four statements showing the PSTs' expectations alongside their perceptions of reality about outdoor learning activities. Data collection related to psychosocial scale was carried out prior to and after the field trip activities. The score on each item shows the level of agreement in the statement item. The statement is made in a favorable condition so that the score on the statement includes "1" = strongly disagree; "2" = disagree; "3" = neutral; "4" = agree; "5" = strongly disagree. This instrument consisted of 28 statements about expectations and 28 statements related to the reality that was experienced in the field trip activities. SOLEI which was previously developed by Orion et al. (1997) consists of 55 items with Cronbach's alpha values (1) 0.55 ; (2) 0.76 ; (3) 0.66 ; (4) 0.71 ; (5) 0.58 ; (6) 0.73 ; (7) 0.60 . The content validity was analyzed by adjusting the content and events arranged. The construct validity and reliability were analyzed through re-testing the modified instrument on 34 PSTs. The validity and reliability of the instrument were analyzed using SPSS software with Bivariate Pearson correlation analysis \& Cronbach's Alpha so that the data obtained as shown in Table 2.

Table 2. Instrument Validity and Reliability

\begin{tabular}{lcccc}
\hline \multirow{2}{*}{ Scale } & \multicolumn{2}{c}{ Perceptions of Expectation } & \multicolumn{2}{c}{ Perceptions of Reality } \\
\cline { 2 - 5 } & $\begin{array}{c}\mathrm{N} \text { (items) } \\
\mathrm{r}>0,3388)\end{array}$ & $\begin{array}{c}\text { Cronbach's } \\
\text { Alpha }\end{array}$ & $\begin{array}{c}\text { N (items) } \\
(\mathrm{r}>0,3388)\end{array}$ & $\begin{array}{c}\text { Cronbach's } \\
\text { Alpha }\end{array}$ \\
\hline Environmental & & & & 0.785 \\
Interaction & 4 & 0.588 & 4 & 0.747 \\
Integration & 4 & 0.876 & 4 & 0.931 \\
Students Cohessiveness & 4 & 0.785 & 4 & 0.804 \\
Teacher Supportiveness & 4 & 0.823 & 4 & 0.828 \\
Open-endedness & 4 & 0.654 & 4 & 0.923 \\
Preparation and & & & 4 & 0.811 \\
Organization & 4 & 0.940 & 4 & \\
Material Environment & 4 & 0.681 & & \\
\hline
\end{tabular}

Qualitative data were analyzed by narrating the activities carried out through the interpretation of photos and vlogs by PSTs. Quantitative data analysis used a chart that shows the difference between the perception of expectations and the reality experienced. The perception of PSTs is also divided into four categories based on the average score per item of the scale statement. Categories that show the strength of perceptions of conditions of expectations and reality include 1.00-1.99 = Very weak; 2.00-2.99 = Weak; 3,00-3,99= Neutral; 4.00-5.00 = Strong. Afterwards the difference condition was categorized through Ngain analysis according to Hake (1998), namely with the criteria $\mathrm{g}<0.3$ (Low Level); $0.3 \leq \mathrm{g}$ $\leq 0.7$ (Medium Level); and $\mathrm{g}>0.7$ (High Level). Further analysis used the Wilcoxon test to show whether there are significant differences in the PSTs' perception conditions. Quantitative data were analyzed using Microsoft Excel and SPSS software.

\section{Findings}

\section{The Field Trip Experiences of Pre-service Science Teachers}

The field trip was designed in such a way that it covered two needs of PSTs which included the need for contextual experiences in natural science knowledge material (biology, chemistry, physics, as well as earth and space science), and pedagogic and teaching sciences. 


\section{Cibodas Botanical Garden}

The visit was held in an open area as well as a house and a garden constructed specifically for plant conservation. This activity was accompanied by additional guides (besides lecturers themselves) who were specifically appointed to clarify issues related to the concept of conservation in the botanical garden area and to make explanations related to the characteristics of each plant encountered by PSTs. This object is related to lectures taken by PSTs; ecology. An overview of the conditions of the visit to this object can be seen in Figure 1. Additionally, the experience gained from each class is summarized on the YouTube channel that can be accessed through the page, Class A: https://www.youtube.com/watch?v=V5gi7XKSKOY \& Class B: https://www.youtube.com/watch?v=sgUKLrG4MhQ
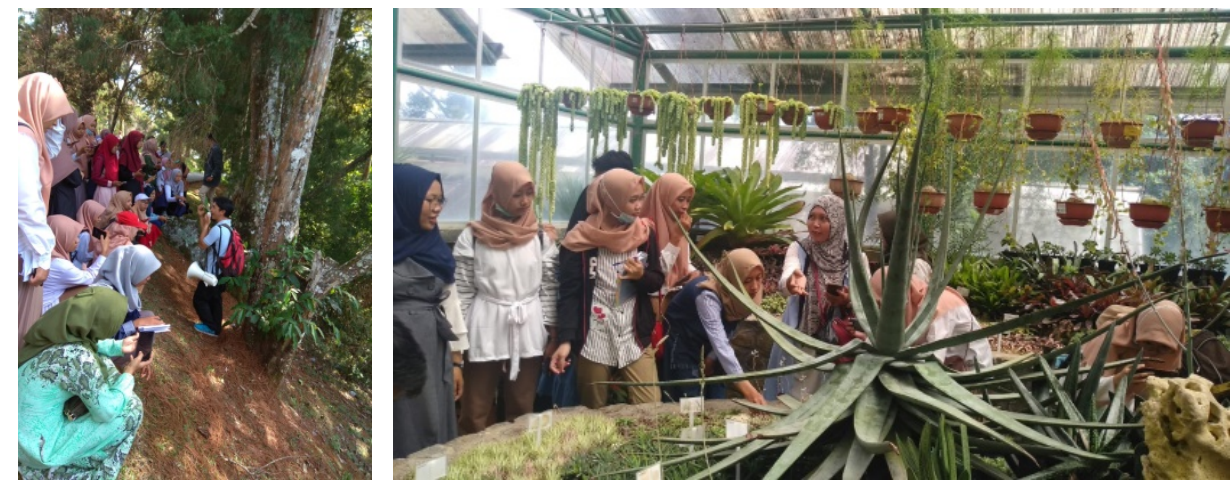

Figure 1. The activities of PSTs in the Cibodas Botanical Garden are dominated by observations of the botanical variety they find throughout the area.

\section{Centre for Demonstration of Science and Technology, Sundial}

This object is related to the course of Media and ICT for Science Learning. On this object, PSTs can try a variety of teaching aids in science. Based on the variety of teaching aids provided, PSTs can be inspired to develop learning media that can be applied to the science teaching process in the future. By trying out the available teaching aids, the PSTs better understand the science concepts they learn. Details of experience in each class can be accessed through the page https://www.youtube.com/watch?v=RQv7DFFPfq0 (Class A) \& https://www.youtube.com/watch? $v=v w 4 S U G F J C u Q$ (Class B). Some of the PSTs' activities in trying out props are shown in Figure 2.
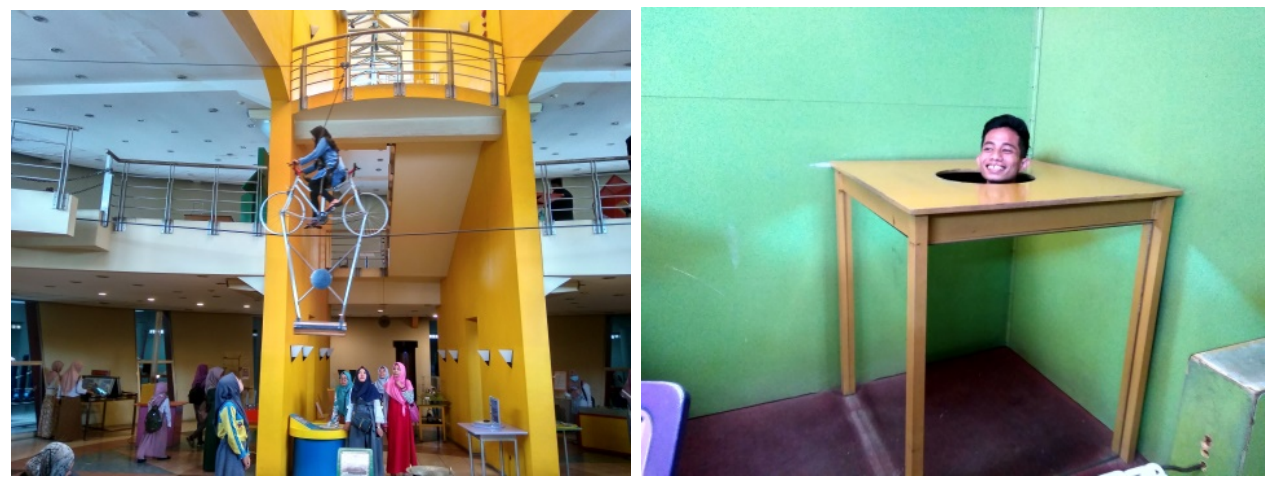

Figure 2. PSTs' activities that are trying out some of the science props at the Centre for Demonstration of Science and Technology, Sundial. 


\section{Natural Sciences Education Study Program, Indonesian University of Education}

Activities are carried out through lecture explanations relating to projections to continue study at the postgraduate level. PSTs also had the opportunity to observe laboratory facilities, as well as management, teaching and learning processes at the university. On this occasion, the PSTs had the opportunity to integrate the knowledge they had acquired in the teaching profession courses with the projected picture of them becoming future teachers and also with the chances of further study. Activities on this object are illustrated in Figure 3., as well as pages on https://www.youtube.com/watch?v=li49a0wvvo (Class A) \& https://www.youtube.com/watch?v=spfqvOeTbv4 (Class B).
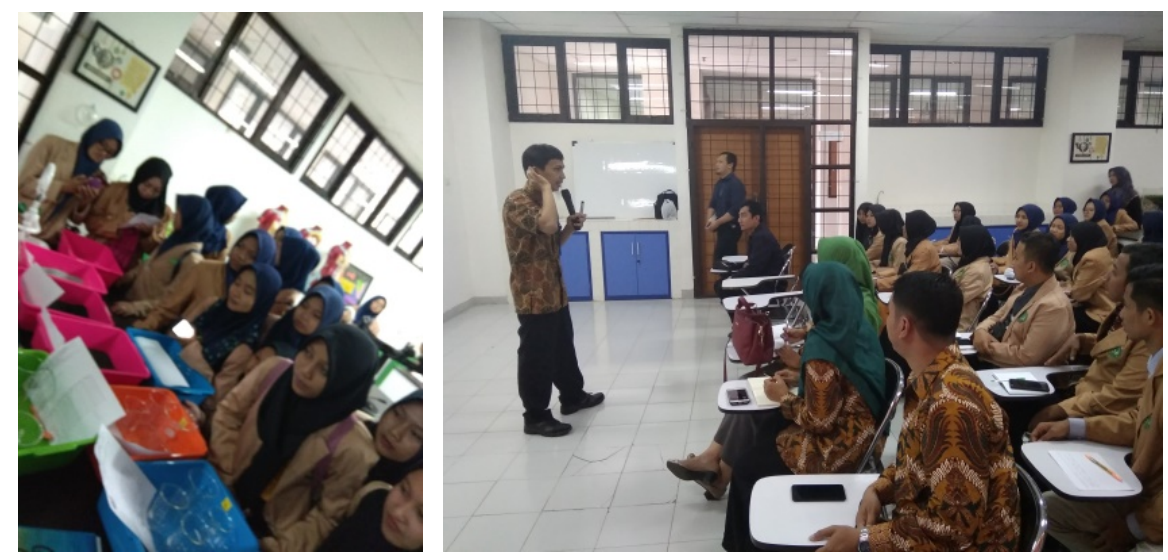

Figure 3. PSTs obtain information and conduct observations of activities related to the learning process in the Natural Sciences Education Study Program, the Indonesian University of Education, both at the Undergraduate and Postgraduate levels.

\section{SEAMEO Regional Centre for Quality Improvement of Teachers and Education Personnel (QITEP) in Science}

The activities carried out at this institution are in the form of activities paying attention to lectures that explain the Southeast Asian regional science education organization and in the form of its work program. PSTs' knowledge about the science teaching profession is not limited to the scope of schools, but also extends to the area of teacher training institutions and educational staff, as well as a variety of organizations engaged in improving the quality of science at the national, regional and international levels.

PSTs also had the opportunity to try out several products by vocational student coaching programs that aimed to develop applications based on augmented reality (AR). The form of this activity is shown in Figure 4. Details of the vlog created by PSTs describing their activities can be accessed at https://www.youtube.com/watch?v=RbGAy3MHOLk (Class A) \& https://www.youtube.com/watch?v=_W3wRcasuvQ (Class B). 

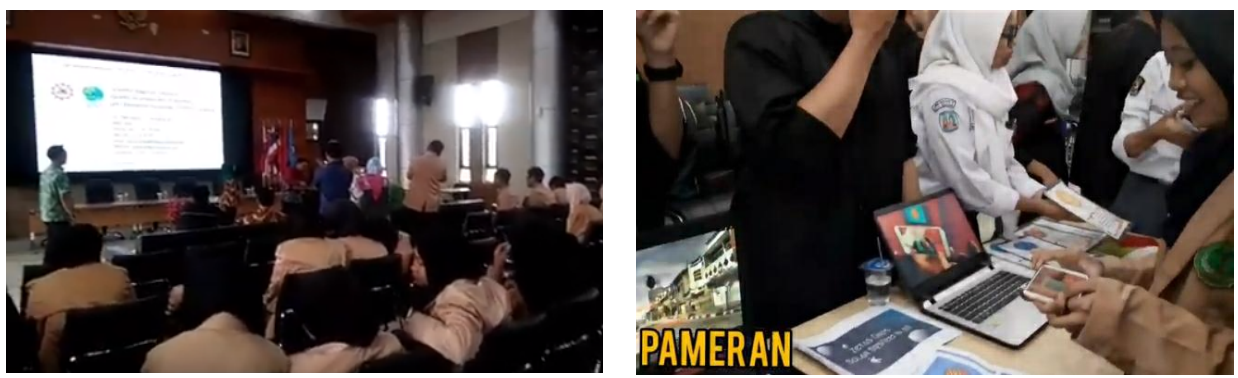

Figure 4. Introduction to the science education organization and its work program through the SEAMEO Regional Center for Quality Improvement of Teachers and Education Personnel (QITEP) in Science

\section{Pudak Scientific}

The activities carried out by the PSTs were in the form of observation of the process of making educational teaching aids, laboratory equipment, and trying out of some science teaching aids. PSTs activities are shown in Figure 5. and can be accessed through https://www.youtube.com/watch?v=hCKSsSmrGRA\&t=30s (Class A) \& https://www.youtube.com/watch?v=IZMTTHHxBRQ\&t=24s (Class B).
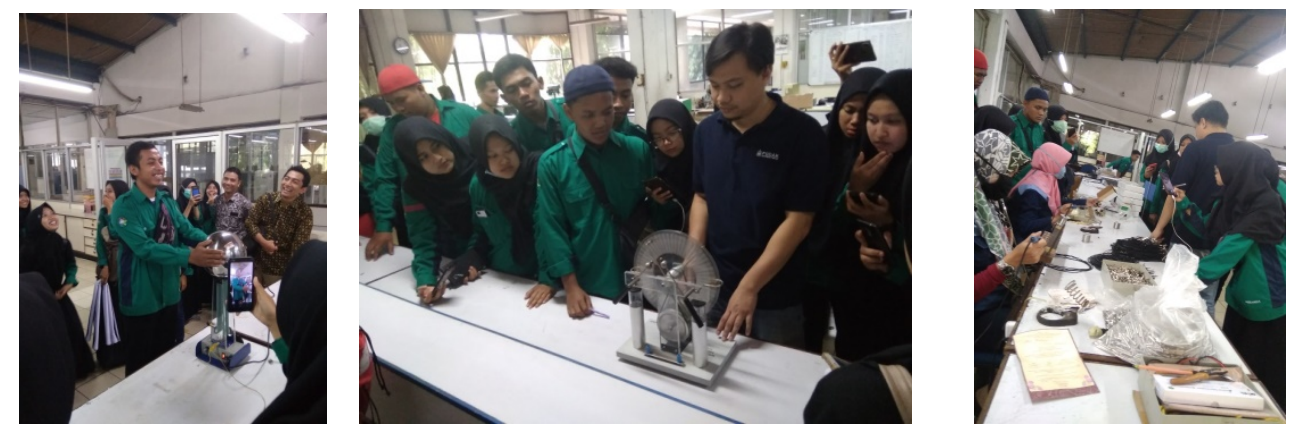

Figure 5. PSTs' activities in the Pudak Factory in the form of observation activities regarding the production of educational aids, as well as in the form of their trying some demonstrations of the use of equipment.

\section{The Boscha Observatory}

PSTs are aware of the application of the knowledge gained through the Earth and Space Sciences courses. That being said, they were given a more detailed explanation related to the use of the largest and oldest observatory in Indonesia. The activities carried out are shown in Figure 6. and can be accessed at https://www.youtube.com/watch?v=OjYRfXO4t5k (Class A) \& https://www.youtube.com/watch?v=hOMchmOEdF8 (Class B). 

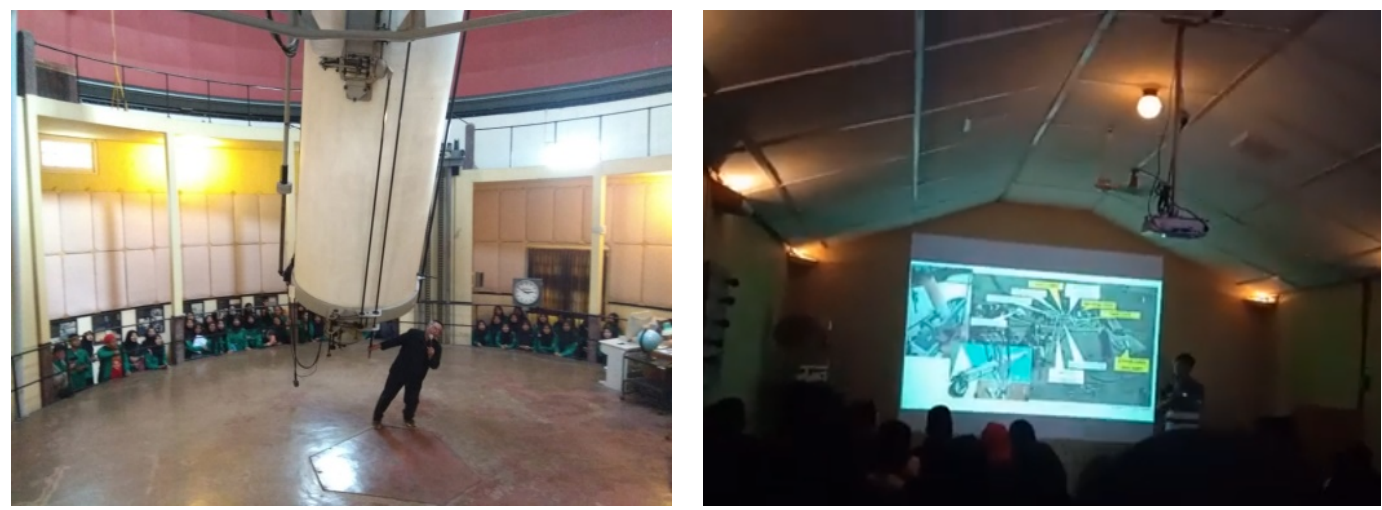

Figure 6. PSTs obtain an explanation of the Boscha Observatory and its Utilization

\section{The Psychosocial Outdoor Learning Environment of Pre-service Science Teachers}

Based on the data obtained by the SOLEI, expectations of PSTs as well as responses to the reality during outdoor activities are attained. Details of the description of the conditions are demosntrated in Figure 7.

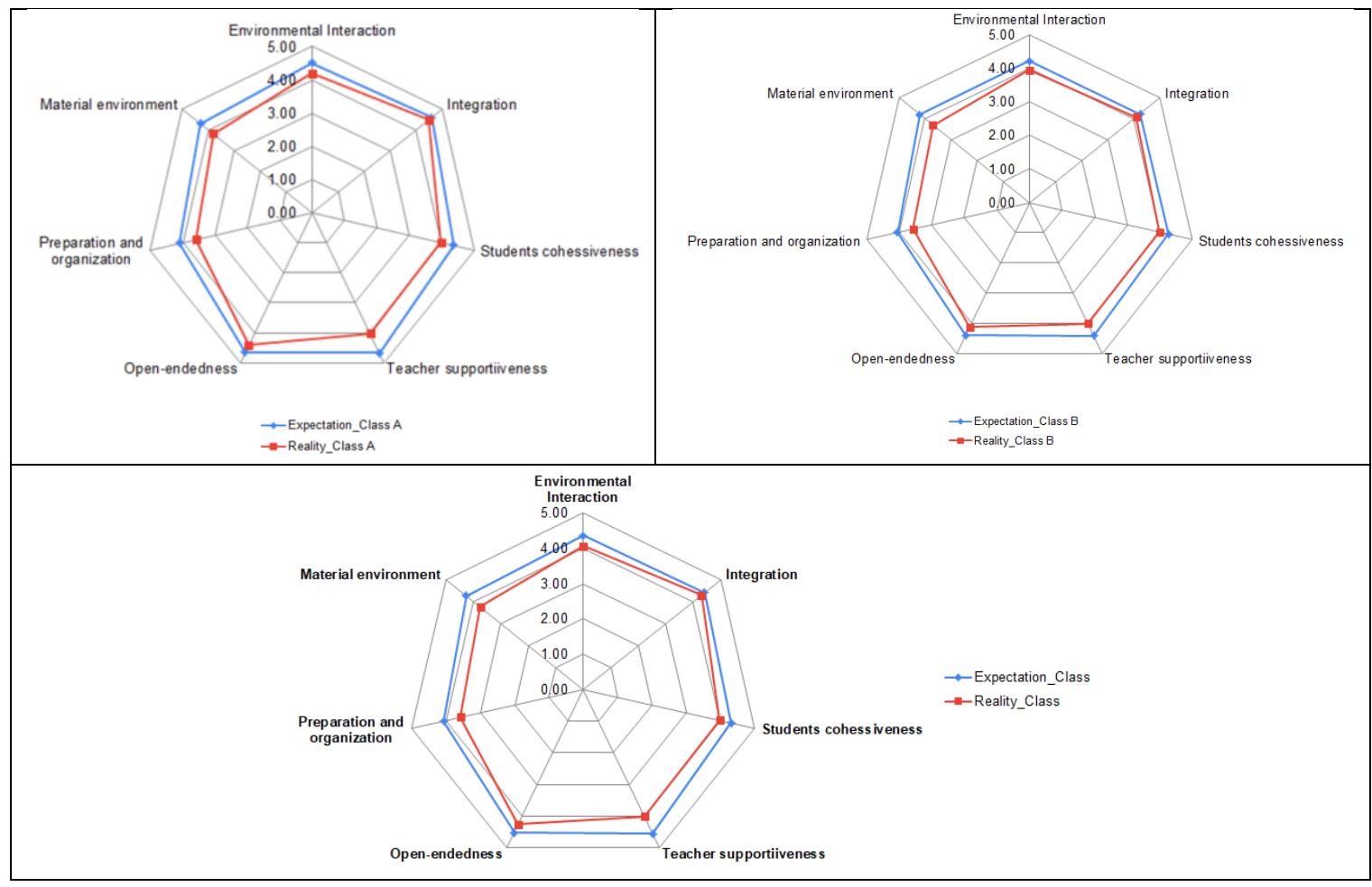

Figure 7. Conditions of Differences in the Descriptions of Expectations and Relativity by PSTs in Classes A, B, and Overall

Figure 7 indicates a decrease between the conditions of PSTs' expectations and the reality obtained when Field Trip activities were conducted. The decrease occurred at all scales which showed the condition of the psychosocial learning environment of PSTs. From this decrease, it can be identified that the lowest decrease is in the integration aspect, and the sharpest decrease is in the teacher supportiveness aspect. Details of these conditions are explained further in Table 3. 
Table 3. Results of the Psychosocial Condition Analysis of Outdoor Learning Environments

\begin{tabular}{|c|c|c|c|c|c|c|c|c|c|c|c|c|}
\hline \multirow[t]{2}{*}{ Scale } & \multicolumn{3}{|c|}{$\begin{array}{l}\text { Mean (SD) of Expectation } \\
\text { Aspect }\end{array}$} & \multicolumn{3}{|c|}{$\begin{array}{llll}\begin{array}{l}\text { Mean } \\
\text { Aspect }\end{array} & & & \\
\end{array}$} & \multicolumn{3}{|c|}{$\begin{array}{l}\text { N-Gain Score Average } \\
\text { (Category) }\end{array}$} & \multicolumn{3}{|l|}{.Sig } \\
\hline & A & $B$ & All & A & B & All & A & B & All & A & $B$ & All \\
\hline EI & $\begin{array}{l}4.50 \\
(0.37)\end{array}$ & $\begin{array}{l}4.22 \\
(0.45)\end{array}$ & $\begin{array}{l}4.36 \\
(0.43) \\
\end{array}$ & $\begin{array}{l}4.19 \\
(0.50) \\
\end{array}$ & $\begin{array}{l}3.95 \\
(0.43) \\
\end{array}$ & $\begin{array}{l}4.07 \\
(0.47)\end{array}$ & $\begin{array}{l}0.26 \\
(\mathrm{~L})\end{array}$ & $\begin{array}{l}0.38 \\
(\mathrm{M})\end{array}$ & $\begin{array}{l}0.31 \\
(\mathrm{M})\end{array}$ & 0.000 & 0.001 & 0.000 \\
\hline IG & $\begin{array}{l}4.59 \\
(0.44) \\
\end{array}$ & $\begin{array}{l}4.24 \\
(0.42) \\
\end{array}$ & $\begin{array}{l}4.41 \\
(0.49)\end{array}$ & $\begin{array}{l}4.49 \\
(0.46)\end{array}$ & $\begin{array}{l}4.09 \\
(0.44) \\
\end{array}$ & $\begin{array}{l}4.28 \\
(0.49) \\
\end{array}$ & $\begin{array}{l}0.17 \\
(\mathrm{~L})\end{array}$ & $\begin{array}{l}0.20 \\
(\mathrm{~L})\end{array}$ & $\begin{array}{l}0.18 \\
(\mathrm{~L})\end{array}$ & 0.193* & $0.068 *$ & $0.027 *$ \\
\hline SC & $\begin{array}{l}4.36 \\
(0.50)\end{array}$ & $\begin{array}{l}4.26 \\
(0.45)\end{array}$ & $\begin{array}{l}4.31 \\
(0.47)\end{array}$ & $\begin{array}{l}3.97 \\
(0.81)\end{array}$ & $\begin{array}{l}3.99 \\
(0.54)\end{array}$ & $\begin{array}{l}3.98 \\
(0.68)\end{array}$ & $\begin{array}{l}0.27 \\
(\mathrm{~L})\end{array}$ & $\begin{array}{l}0.38 \\
(\mathrm{M})\end{array}$ & $\begin{array}{l}0.33 \\
(\mathrm{M})\end{array}$ & 0.002 & 0.005 & 0.000 \\
\hline TS & $\begin{array}{l}4.68 \\
(0.42)\end{array}$ & $\begin{array}{l}4.42 \\
(0.47)\end{array}$ & $\begin{array}{l}4.55 \\
(0.46)\end{array}$ & $\begin{array}{l}4.02 \\
(0.61)\end{array}$ & $\begin{array}{l}4.01 \\
(0.45)\end{array}$ & $\begin{array}{l}4.02 \\
(0.53)\end{array}$ & $\begin{array}{l}0.42 \\
(\mathrm{M})\end{array}$ & $\begin{array}{l}0.67 \\
(\mathrm{M})\end{array}$ & $\begin{array}{l}0.54 \\
(\mathrm{M})\end{array}$ & 0.000 & 0.001 & 0.000 \\
\hline $\mathrm{OE}$ & $\begin{array}{l}4.65 \\
(0.34)\end{array}$ & $\begin{array}{l}4.40 \\
(0.42) \\
\end{array}$ & $\begin{array}{l}4.52 \\
(0.40)\end{array}$ & $\begin{array}{l}4.40 \\
(0.52) \\
\end{array}$ & $\begin{array}{l}4.13 \\
(0.42) \\
\end{array}$ & $\begin{array}{l}4.26 \\
(0.49) \\
\end{array}$ & $\begin{array}{l}0.31 \\
(\mathrm{M})\end{array}$ & $\begin{array}{l}0.42 \\
(\mathrm{M})\end{array}$ & $\begin{array}{l}0.35 \\
(\mathrm{M})\end{array}$ & 0.006 & 0.003 & 0.000 \\
\hline PO & $\begin{array}{l}4.09 \\
(0.82)\end{array}$ & $\begin{array}{l}4.06 \\
(0.53)\end{array}$ & $\begin{array}{l}4.07 \\
(0.68)\end{array}$ & $\begin{array}{l}3.59 \\
(0.82)\end{array}$ & $\begin{array}{l}3.57 \\
(0.58)\end{array}$ & $\begin{array}{l}3.58 \\
(0.70)\end{array}$ & $\begin{array}{l}0.34 \\
(\mathrm{M})\end{array}$ & $\begin{array}{l}0.35 \\
(\mathrm{M})\end{array}$ & $\begin{array}{l}0.35 \\
\text { (M) }\end{array}$ & 0.000 & 0.000 & 0.000 \\
\hline ME & $\begin{array}{l}4.31 \\
(0.53) \\
\end{array}$ & $\begin{array}{l}4.20 \\
(0.45) \\
\end{array}$ & $\begin{array}{l}4.25 \\
(0.49) \\
\end{array}$ & $\begin{array}{ll}3.81 \\
(0.72) \\
\end{array}$ & $\begin{array}{l}3.69 \\
(0.53) \\
\end{array}$ & $\begin{array}{ll}3.75 \\
(0.63) \\
\end{array}$ & $\begin{array}{l}0.39 \\
(\mathrm{M})\end{array}$ & $\begin{array}{l}0.42 \\
\text { (M) }\end{array}$ & $\begin{array}{l}0.40 \\
(\mathrm{M}) \\
\end{array}$ & 0.000 & 0.000 & 0.000 \\
\hline Overall & $\begin{array}{l}4.45 \\
(0.35) \\
\end{array}$ & $\begin{array}{l}4.26 \\
(0.34) \\
\end{array}$ & $\begin{array}{l}4.35 \\
(0.36)\end{array}$ & $\begin{array}{l}4.07 \\
(0.44)\end{array}$ & $\begin{array}{l}3.92 \\
(0.38) \\
\end{array}$ & $\begin{array}{l}3.99 \\
(0.41) \\
\end{array}$ & $\begin{array}{l}0.31 \\
(\mathrm{M}) \\
\end{array}$ & $\begin{array}{l}0.41 \\
(\mathrm{M})\end{array}$ & $\begin{array}{l}0.36 \\
(\mathrm{M})\end{array}$ & 0.000 & 0.000 & 0.000 \\
\hline
\end{tabular}

\section{Note:}

$\mathrm{EI}=$ Environmental Interaction;

$\mathrm{IG}=$ Integration;

$\mathrm{SC}=$ Students cohesiveness;

$\mathrm{TS}=$ Teacher supportiveness;

$\mathrm{OE}=$ Open-endedness;

$\mathrm{PO}=$ Preparation and organization;

$\mathrm{ME}=$ Material environment;

$=$ Strong Perception Category
$=$ Neutral Perception Category

$\mathrm{L}=$ Low level;

$\mathrm{M}=$ Medium Level.

* = The null hypothesis is accepted, there is no significant difference in the perception of expectations and reality;

Table 3. shows that the average psychosocial condition of PSTs both in Class A, B, and as a whole is significantly different, except on the scale of integration. The different conditions of the average $\mathrm{N}$-Gain Score on each scale presented a difference in the medium and low categories. This includes what happened to both classes. Expectations and reality responses from Class A on the scale of environmental interaction, integration, and student cohesiveness differ in the medium category, but for Class B this only happens on the scale of integration and is left on the medium category. Overall, the average N-Gain score on the integration scale is at a low level, whilst the other scales are at the medium level. The change in perception categories from strong to neutral occurs in components that include student cohesiveness, preparation and organization, and material environment.

\section{Discussion}

Field trips are activities designed for PSTs that integrate curriculum components, visiting objects, lecturers or lectures, and instructors in the visiting objects. This field trip is linked with lecturer support in the process of preparing the material, organizing the activities, the instruction in class, and explanations through outdoor activities. This is witnessed in Figure 8. The selection of the right visiting object is of crucial importance. Field trip activities stimulate actual experiences of students in locations that are authentic, unique which otherwise cannot be realized in classroom learning. Each student developed a unique meaning in their experiences with the object of the visit (Behrendt \& Franklin, 2014). Science content and educational theories delivered in lectures become more relevant when students assimilate and accommodate the novelty of comprehension. The link between field trips and the classrooms connects the field trip experiences with previous classroom experiences (Lei, 2010) in a meaningful fashion. The purposes of this field trip are to provide hands-on experience, to encourage interest and motivation in the field of science studies and science education, to connect classroom learning with real conditions, to strengthen observation skills, and lastly to contribute to the development of personal skills (Michie, 1998). 


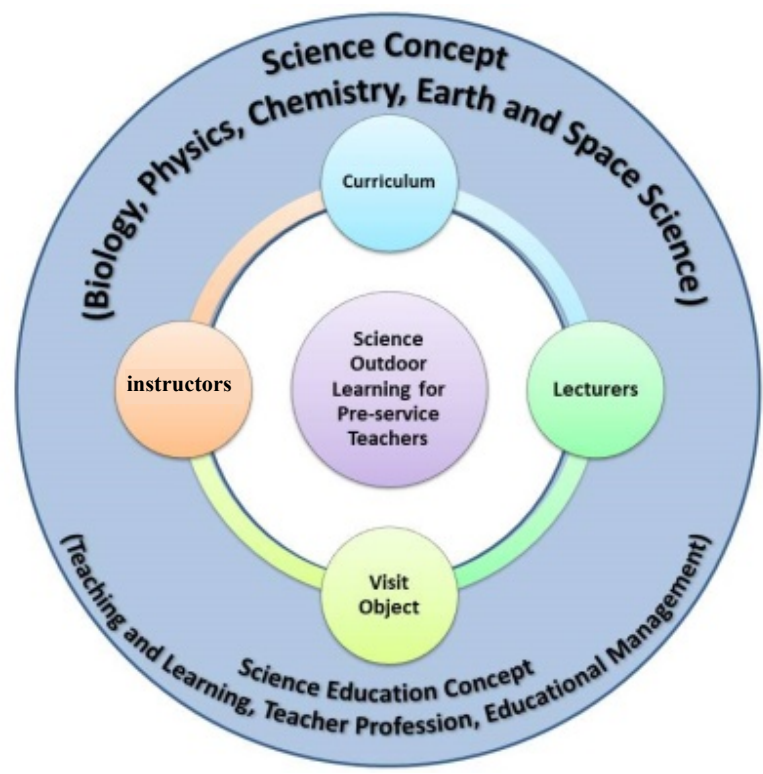

Figure 8. Field Trip concept patterns for PSTs

\section{Environmental Interaction}

Environmental interaction conditions indicate the extent to which PSTs interact in groups or with the environment on the visit object. These interactions include how PSTs find interesting phenomena and explore the information related to scientific and pedagogical content. This can also be in the form of active involvement through discussions, question and answer sessions, and observations. There is a decrease in the medium level that occurs in the expectations and reality experienced by PSTs, although there is no change in the perception categories, both of which are at strong levels. This shows PSTs are aware of the need, and interactions take place during field trip activities. The field trip emphasizes the teaching of science inductively with a student-centred approach to the environment (Arianti \& Aminatun, 2019)

\section{Integration}

This component finally shows the perception of the PSTs on the relationship of class lectures with information from the visit object. The information obtained from the field trip can better explain the concepts and theories that are shared in lectures, and can help solve problems encountered during lectures as well the potential problems in future professional life. Outdoor learning activities are recommended in teaching science, especially when learning about the environment and nature (Education \& Development, 2019). Field trips can motivate students to appreciate and understand the concepts taught in the classroom (Ramachandiran \& Dhanapal, 2016). In the design that has been implemented, the expectations and the reality experienced by PSTs are not significantly different, both of which are strongly perceived.

\section{Students cohesiveness}

Field trips are expected to increase collaboration between PSTs to observe visiting objects. Field trips are not limited to observation, on the contrary, they become a means of 
active discussion activities, as well as collaboration in completing tasks and targets in groups. Thus, this field trip improves the quality of communication within groups and amongst groups of PSTs for complete data acquisition. In the implementation of field trip design, the condition of this aspect is significantly different and there is both a decrease and change in the category of perception from strong to neutral. In this case, personal and group dynamics might be possible during field trip activities. The dynamics show the conditions of decline between expectations at the beginning of field trip activities, the process, and evaluation of field trip activities through the completion of targets and tasks. Referring to the category of two classes, both have the same intimacy based on their expectations of field trip activities, but the intimacy of the category changes based on the reality of the field trip implementation. The aspect of student cohesiveness is not only the aspect of collaboration that occurs in PSTs but also the emotional relationships that are true for activities executed together (Chang et al., 2018; Orion et al., 1997). Nonetheless, classes A and B have different categories at the N-gain score level, where the former is at a low level, and the latter is at the medium level. This tells that in class A, PSTs tend to be more satisfied with the emotional aspects of class members in completing targets and assignments on field trips. In a similar vein, research underlined that outdoor activities can strengthen friendships (Education \& Development, 2019).

\section{Teacher supportiveness}

The teachers, in this case, were a group of lecturers, instructors, or speakers in the visiting area. The role of the lecturer gives direction to the items that must be observed on the object. In addition to the support from lecturers, during the visit, PSTs also received explanations relating to science content or pedagogical content by guides and speakers. PSTs get support from lecturers, guides, and resource persons in various ways including cognitive, emotional, and social ways (Chang et al., 2018). The support of this component will have an impact on the clarity of activities that must be carried out by PSTs, as well as on dealing with obstacles encountered by PSTs on the object of the visit. The existence of teachers who are full of enthusiasm and competence is identified as one of the most effective factors influencing students' scientific perceptions (Shirazi, 2017; Yung et al., 2013). Although the survey results denote a decrease in the $\mathrm{N}$-gain score and significant differences in expectations and reality, the condition of perceived support by PSTs is still at a strong level and imply no change. Thusly, support from lecturers, guides, or speakers in directing the knowledge of PSTs is sufficient in the implementation of field trip design. The permanent presence of a lecturer or class educator is not required to achieve success in outdoor learning though. Outdoor learning is possible to be implemented constructively (Glaab \& Heyne, 2019).

\section{Open-endedness}

Field trips are expected to develop personal thinking skills in understanding science and pedagogical concepts. The visiting objects that are designed in field trip activities can provide an overview of the content of science and the teaching profession in the future. PSTs can be more critical and find other perspectives in seeing a variety of natural science phenomena and pedagogical learning of science. With the help of field trips, PSTs gained new forms of knowledge and could materialize theoretical/abstract knowledge, and increased their memory retention (Bozdoğan, 2018). The perception of PSTs related to the aspect of openendedness did not change in categories both before and after the activity (strong category), although there is a decrease in N-gain score at the medium level, as well as some significant 
differences. This field trip eliminates inadequacy of information flow to PSTs during the process of learning (Bozdoğan, 2016). As an example to that, PSTs became aware of the process of observing celestial bodies and the exact reason for the location of the observatory built by Boscha.

\section{Preparation and organization}

This dimension is the extent to which PSTs and educators prepare and organize field trip activities. Preparations for outdoor learning activities entail cognitive, geographical, and psychological preparations (Orion \& Hofstein, 1994). PSTs are expected to get an overview related to field trip objects via the internet, and to understand the relationship between science content and science pedagogics with field trip objects. The list of activities that must be carried out by the PSTs has also been arranged and is equipped with references, as well as tools and materials needed. A change noted in the category from strong to neutral in addition to significant decreases and differences. This is because the majority of PSTs for the first time do field trip activities that require them to make detailed observations on the object of the visit. They also firstly carried out a visit to the objects specified in this field trip. The number of objects that have an effect on the amount of knowledge must be visited in a short amount of time. Notwithstanding, the results of previous research underpinned that gaining a little renewal of knowledge has a positive effect, but too much renewal can stand in the way of the learning process (Boeve-de Pauw et al., 2019).

\section{Material environment}

This scale shows the extent to which PSTs are given information and the uses of information related to outdoor learning activities. This is also very related to the other aspects such as preparation and organization. The required material is available in-class lectures followed by PSTs. By ensuring a good organization, PSTs are expected to have obtained detailed objectives of activities on each object. In this activity, PSTs are also given a list of questions, as well as aspects that must be observed in the activity. The conditions of perception of expectation and reality change categories from strong to neutral. This can occur owing to PSTs' self-regulated learning and because of the fact that details of activities are not fully grasped by PSTs. With that being said, the decrease in the N-Gain score is still at the medium level. PSTs can learn more deeply through objects they face outside the classroom. Outdoor learning is more challenging for students to relate theoretical material in books and reality in the field so that the concepts can be processed well (Arianti \& Aminatun, 2019). The outdoor environment is a rich source of learning that can liven up the atmosphere that is so heavy with over dependence on books and the traditional classroom atmosphere (Özgen, 2011; Tatar \& Bağriyanik, 2012).

\section{Conclusion}

The field trip design for PSTs recommends activities that lead to observation and exploration of visiting objects relating not only to the content of the science but also to the pedagogical aspects of the science. The visiting object is integrated with lectures taken by PSTs. Apace with visiting objects, class lectures should also be integrated with the needs of the visit and learning process needs to be planned appropriately.

In general, the psychosocial aspects of PSTs reveal that field trip activities signialled a positive meaning in all aspects, although there are significant differences in the conditions of 
expectations and reality. The integration aspect is not significantly different. The decline in perception is still at the medium level, but the condition of the perception is still at a positive level. This positive perception condition can prevent PSTs from failing to fully utilize the environmental gains in the future (Bozdoğan, 2016). The results of this research are beneficial for teacher education as they highlight the ability to integrate the teaching and learning process with nature and outdoor learning environments. Pedagogically good techniques can have an impact on the professional skills of prospective teachers (Kangas et al., 2018). Research and development studies that emphasize the process of integrating classroom learning with outdoor activities can be carried out further to be able to give meaning to science learning, which is not limited by classrooms or laboratories.

\section{Acknowledgment}

We would like to thank the financial support of the Institut Agama Islam Negeri Kudus. Secondly, we would also like to thank all of you who have helped collect research data that includes pre-service science teachers from IAIN Kudus who are class A and B, class of 2017/2018; Cibodas Botanical Garden; Centre for Demonstration of Science and Technology, Sundial; Natural Sciences Education Study Program, Indonesian University of Education; SEAMEO Regional Centre for Quality Improvement of Teachers and Education Personnel (QITEP) in Science; Pudak Scientific; and Boscha Observatory. We are also grateful for the collaboration with Kasetsart University.

\section{References}

Ahmad, C. N. C., Osman, K., \& Halim, L. (2012). Relationship Between Physical and Psychosocial Aspects in Science Laboratory Learning Environment. Procedia - Social and Behavioral Sciences, 46, 1500-1505. https://doi.org/10.1016/j.sbspro.2012.05.329

Arianti, Y., \& Aminatun, T. (2019). An analysis of outdoor learning towards students' outcomes in learning biology. Journal of Physics: Conference Series, 1241(1). https://doi.org/10.1088/1742-6596/1241/1/012061

Ash, D., \& Wells, G. (2006). Dialogic Inquiry in Classroom and Museum. In N. C. Z. Bekerman, B. Burbles, \& D. Silberman-Keller (Ed.), The Informal Education Reader (hal. 35-54). Peter Lang.

Ballantyne, R., Packer, J., Hughes, K., \& Dierking, L. (2007). Conservation learning in wildlife tourism settings: lessons from research in zoos and aquariums. Environmental Education Research, 13(3), 367-383. https://doi.org/10.1080/13504620701430604

Bamberger, Y., \& Tal, T. (2008). Multiple outcomes of class visits to natural history museums: The students' view. Journal of Science Education and Technology, 17(3), 274-284. https://doi.org/10.1007/s10956-008-9097-3

Behrendt, M., \& Franklin, T. (2014). A Review of Research on School Field Trips and Their Value in Education. 3, 235-245. https://doi.org/10.12973/ijese.2014.213a

Bell, P., Lewenstein, B., Shouse, A. W., \& Feder, M. A. (2009). Learning Science in Informal Environments: People, Places and Pursuits. The National Academies Press.

Boeve-de Pauw, J., Van Hoof, J., \& Van Petegem, P. (2019). Effective field trips in nature: the interplay between novelty and learning. Journal of Biological Education, 53(1), 21-33. https://doi.org/10.1080/00219266.2017.1418760

Bozdoğan, A. E. (2016). The Effect of Planetarium Trip on Pre-Service Science Teachers' Metaphorical Perceptions about Planetariums. Malaysian Online Journal of Educational Sciences, 4(4), 70-84. 
Bozdoğan, A. E. (2018). Determination of Turkish Prospective Teachers' Past Field Trip Experiences and Examination of Their Self-Efficacy Beliefs in Planning and Organising Educational Field Trips Regarding Various Variables. Participatory Educational Research, 5(2), 1-17. https://doi.org/10.17275/per.18.8.5.2

Caires, S., Almeida, L., \& Vieira, D. (2012). Becoming a teacher: Student teachers' experiences and perceptions about teaching practice. European Journal of Teacher Education, 35(2), 163-178. https://doi.org/10.1080/02619768.2011.643395

Chang, J., Faikhamta, C., Na, J., \& Song, J. (2018). A comparison of science classroom environments between Korea and Thailand with a focus on their cultural features. Asia-Pacific Science Education, 4(1), 1-22. https://doi.org/10.1186/s41029-018-00281

Cohen, L., Manion, L., \& Morrison, K. (2007). Research Methods in Education (Sixth Edit). Routledge.

Dillon, J., Rickinson, M., Teamey, K., Morris, M., Choi, M. Y., Sanders, D., \& Benefield, P. (2016). The value of outdoor learning: Evidence from research in the UK and elsewhere. Towards a Convergence Between Science and Environmental Education: The selected works of Justin Dillon, January, 179-185. https://doi.org/10.4324/9781315730486

Djonko-moore, C. M., \& Joseph, N. M. (2016). Out of the Classroom and Into the City: The Use of Field Trips as an Experiential Learning Tool in Teacher Education. SAGE Open, 1-13. https://doi.org/10.1177/2158244016649648

Education, S., \& Development, C. (2019). Analysis of the influence of outdoor education activities on seventh grade students Erol TAŞ. 6(2), 122-143.

Falk, J. H., \& Balling, J. D. (1982). The field trip milieu: Learning and behavior as a function of contextual events. Journal of Educational Research, 76(1), 22-28. https://doi.org/10.1080/00220671.1982.10885418

Fido, H. S. A., \& Gaylord, C. G. (1982). Field work and the biology teacher: A survey in secondary schools in England and Wales. Journal of Biological Education, 16(1), 27 34. https://doi.org/10.1080/00219266.1982.9654414

Fraser, B. J., \& Treagust, D. F. (1986). Validation and Application of the College and University Classroom Environment Inventory (CUCEI). American Educational Research Association, 1-25.

Glaab, S., \& Heyne, T. (2019). Focus wildlife park: Outdoor learning at workstations for primary school children. Applied Environmental Education and Communication, 114. https://doi.org/10.1080/1533015X.2018.1554461

Hake, R. R. (1998). Interactive-engagement versus traditional methods: A six-thousandstudent survey of mechanics test data for introductory physics courses. American Journal of Physics, 66(1), 64-74. https://doi.org/10.1119/1.18809

Hofstein, A., \& Rosenfeld, S. (1996). Bridging the gap between formal and informal science learning. Studies in Science Education, 28(1), 87-112. https://doi.org/10.1080/03057269608560085

Kangas, M., Vuojärvi, H., \& Siklander, P. (2018). Hiking in the wilderness: Interplay between teachers' and students' agencies in outdoor learning. Education in the North, 25(3), 7 31.

Knapp, D., \& Barrie, E. (2001). Content evaluation of an environmental science field trip. Journal of Science Education and Technology, 10(4), 351-357. https://doi.org/10.1023/A:1012247203157

Lei, S. A. (2010). Field trips in college biology and ecology courses: Revisiting benefits anddrawbacks. Journal of Instructional Psychology, 37(1), 42-48. 
Marcus, A. (2008). Rethinking museums' adult education for K-12 teachers. Journal of Museum Education, 33, 55-78.

Martin, S. (2006). Where practice and theory intersect in the chemistry classroom: Using cogenerative dialogue to identify the critical point in science education. Cultural Studies of Science Education, 1(4), 693-720. https://doi.org/10.1007/s11422-0069031-z

McKenzie, G., Utgard, R., \& Lisowski, M. (1986). The importance of field trip: A geological example. Journal of College Science Teaching, 16, 17-20.

Michie, M. (1998). Factors influencing secondary science teachers to organise and conduct field trips. Australian Science Teacher's Journal, 44, 43-50.

Morag, O., \& Tal, T. (2012). Assessing Learning in the Outdoors with the Field Trip in Natural Environments (FiNE) Framework. International Journal of Science Education, 34(5), 745-777. https://doi.org/10.1080/09500693.2011.599046

Nadelson, L. S., Jordan, J. R., \& Jordan, J. R. (2012). Student Attitudes Toward and Recall of Outside Day: An Environmental. October 2014, 37-41. https://doi.org/10.1080/00220671.2011.576715

Olgun, Ö. S. (2009). Engaging elementary preservice teachers with active learning teaching methodologies. Teacher Educator, 44(2), 113-125. https://doi.org/10.1080/08878730902721772

Orion, N., \& Hofstein, A. (1994). Factors that influence learning during a scientific field trip in a natural environment. Journal of Research in Science Teaching, 31(10), 10971119. https://doi.org/10.1002/tea.3660311005

Orion, N., Hofstein, A., Tamir, P., \& Gidding, G. J. (1997). Development and Validation of an Instrument for Assessing Mathematics Classroom Environment in Tertiary Institutions. Science Education, 81, 161-171. https://doi.org/10.1007/s40299-0130138-1

Özgen, N. (2011). A different approach to physical geography teaching method: Tripobservation supported education. Marmara Journal of Geography, 23, 373-388.

Ramachandiran, M., \& Dhanapal, S. (2016). Evaluation of the Effectiveness of Field Trips in the Teaching and Learning of Biosciences. In S. F. Tang \& L. Logonnathan (Ed.), Assessment for Learning Within and Beyond the Classroom. Springer Science+Business Media Singapore. https://doi.org/10.1007/978-981-10-0908-2

Rickinson, M., Dillon, J., Teamey, K., Morris, M., Choi, M. Y., Sanders, D., \& Benefield, P. (2004). A review of research on outdoor learning (Nomor March).

Shirazi, S. (2017). Student experience of school science. International Journal of Science Education, 39(14), 1891-1912. https://doi.org/10.1080/09500693.2017.1356943

Tatar, N., \& Bağriyanik, K. E. (2012). Opinions of Science and Technology Teachers about Outdoor Education. Elementary Education Online, 11(4), 883-896.

Yung, B. H. W., Zhu, Y., Wong, S. L., Cheng, M. W., \& Lo, F. Y. (2013). Teachers' and Students' Conceptions of Good Science Teaching. International Journal of Science Education, 35(14), 2435-2461. ttps://doi.org/10.1080/09500693.2011.629375 